\title{
Microsatellite Mutator Phenotype
}

National Cancer Institute

\section{Source}

National Cancer Institute. Microsatellite Mutator Phenotype. NCI Thesaurus. Code C18522.

A genetic marker phenotype found in some cancers, this condition is marked by the presence of hundreds to thousands of mutations in microsatellite regions of chromosomes. These mutations are associated with decreased fidelity of DNA replication. 